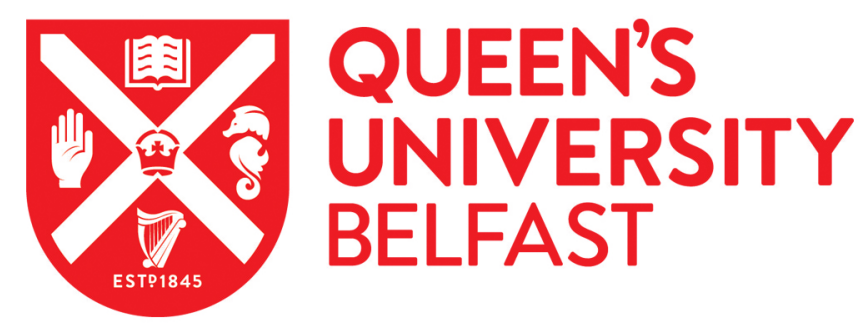

\title{
Air pollutant contamination and acidification of surface waters in the North York Moors, UK: Multi-proxy evidence from the sediments of a moorland pool
}

Battarbee, R. W., Turner, S., Yang, H., Rose, N. L., Smyntek, P. M., Reimer, P. J., Oldfield, F., Jones, V. J., Flower, R. J., Roe, K., Shilland, E., \& Blaauw, M. (2015). Air pollutant contamination and acidification of surface waters in the North York Moors, UK: Multi-proxy evidence from the sediments of a moorland pool. The Holocene, 25(1), 226-237. https://doi.org/10.1177/0959683614556380

Published in:

The Holocene

Document Version:

Publisher's PDF, also known as Version of record

Queen's University Belfast - Research Portal:

Link to publication record in Queen's University Belfast Research Portal

\section{Publisher rights}

This is an open access article published under a Creative Commons Attribution License (https://creativecommons.org/licenses/by/3.0/), which permits unrestricted use, distribution and reproduction in any medium, provided the author and source are cited.

\section{General rights}

Copyright for the publications made accessible via the Queen's University Belfast Research Portal is retained by the author(s) and / or other copyright owners and it is a condition of accessing these publications that users recognise and abide by the legal requirements associated with these rights.

Take down policy

The Research Portal is Queen's institutional repository that provides access to Queen's research output. Every effort has been made to ensure that content in the Research Portal does not infringe any person's rights, or applicable UK laws. If you discover content in the Research Portal that you believe breaches copyright or violates any law, please contact openaccess@qub.ac.uk. 


\title{
Air pollutant contamination and acidification of surface waters in the North York Moors, UK: Multi-proxy evidence from the sediments of a moorland pool
}

\author{
Richard W Battarbee,' Simon Turner,' Handong Yang,' Neil \\ L Rose,' Peter M Smyntek, ${ }^{1,3}$ Paula J Reimer, ${ }^{2}$ Frank Oldfield, ${ }^{4}$ \\ Vivienne J Jones,' Roger J Flower,' Kevin Roe,' Ewan Shilland' and \\ Maarten Blaauw ${ }^{2}$
}

\begin{abstract}
Despite the extensive geographical range of palaeolimnological studies designed to assess the extent of surface water acidification in the United Kingdom during the 1980s, little attention was paid to the status of surface waters in the North York Moors (NYM). In this paper, we present sediment core data from a moorland pool in the NYM that provide a record of air pollution contamination and surface water acidification. The 4I-cm-long core was divided into three lithostratigraphic units. The lower two comprise peaty soils and peats, respectively, that date to between approximately 8080 and 6740 cal. BP. The uppermost unit comprises peaty lake muds dating from between approximately AD I790 and the present day (AD 2006). The lower two units contain pollen dominated by forest taxa, whereas the uppermost unit contains pollen indicative of open landscape conditions similar to those of the present. Heavy metal, spheroidal carbonaceous particle, mineral magnetics and stable isotope analysis of the upper sediments show clear evidence of contamination by air pollutants derived from fossil-fuel combustion over the last c. I50years, and diatom analysis indicates that the naturally acidic pool became more acidic during the 20th century. We conclude that the exceptionally acidic surface waters of the pool at present ( $\mathrm{pH}=\mathrm{c}$. $4 . \mathrm{I}$ ) are the result of a long history of air pollution and not because of naturally acidic local conditions. We argue that the highly acidic surface waters elsewhere in the NYM are similarly acidified and that the lack of evidence of significant recovery from acidification, despite major reductions in the emissions of acidic gases that have taken place over the last c. 30 years, indicates the continuing influence of pollutant sulphur stored in catchment peats, a legacy of over I50years of acid deposition.
\end{abstract}

\section{Keywords}

air pollution, diatom analysis, geochemistry, magnetic measurements, North York Moors, pollen analysis, spheroidal carbonaceous particles, stable isotopes, surface water acidification

Received I7 March 20I4; revised manuscript accepted I0 August 2014

\section{Introduction}

The problem of 'surface water acidification' was first identified in the United Kingdom (by Wright et al., 1980) following a chemical and biological survey of streams and lakes in Galloway, southwest Scotland. They maintained that the highly acidic waters in the region were similar in character to those in parts of southern Norway and southwest Sweden where the loss of salmonid fish populations had been previously documented (Almer et al., 1974; Jensen and Snekvik, 1972). They attributed the cause to the deposition of long-distance transported air pollutants from fossil-fuel combustion sources. Research in Scotland in the following years (Battarbee et al., 1985; Flower and Battarbee, 1983; Harriman and Morrison, 1982; Mason, 1990) supported this explanation, and an extensive palaeolimnological study of low-alkalinity lakes across the United Kingdom demonstrated that surface water acidification caused by 'acid rain' had occurred in the sensitive areas of almost all upland regions of the country (Battarbee et al., 1988).

A national programme to reduce sulphur emissions from UK power stations was consequently introduced, and the UK Acid
Waters Monitoring Network (UK AWMN) was established to track the chemical and biological response of acidified waters to the planned reduction in emissions (Patrick et al., 1991). The Network included 11 lakes and 11 streams (Patrick et al., 1991) designed to be representative of all acidified regions in the country. However, only one site, a stream site, was included in the Pennines, and there was no site in the North York Moors (NYM). These upland regions of Northern England, although dominated

\footnotetext{
'University College London, UK ${ }^{2}$ Queen's University Belfast, UK ${ }^{3}$ Queen Mary University of London, UK ${ }^{4}$ University of Liverpool, UK
}

\section{Corresponding author:}

Richard W Battarbee, Environmental Change Research Centre, University College London, Gower Street, London WCIE 6BT, UK. Email: r.battarbee@ucl.ac.uk 


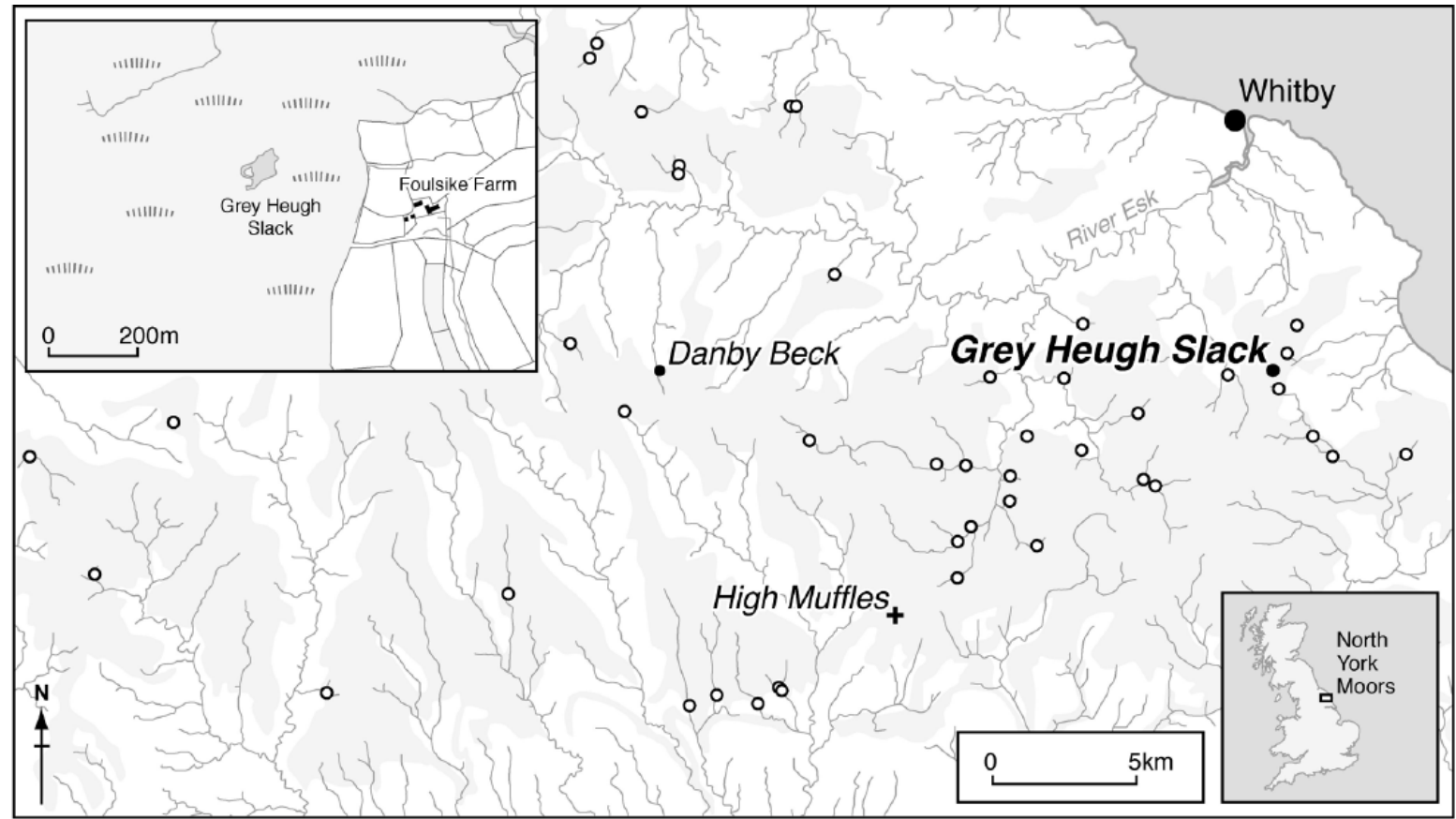

Figure I. Map of the North York Moors (NYM) showing the distribution of soils sensitive to acidification (shaded), the location of stream and pool sites sampled by Evans et al. (2014) (open and closed circles), Danby Beck and Grey Heugh Slack (closed circles) and the UK Acid Deposition Monitoring Network site of High Muffles (cross). The two inset maps show the location of the NYM within Great Britain and the location of Grey Heugh Slack. The latter shows the setting of the pool within the moorland and its proximity to the moorland border and to Foulsike Farm.

by moorland with acidic, peaty soils and acid waters and lying in areas of high acid deposition, contain few natural lakes with none sensitive to acid deposition. Consequently, the extent to which these regions were acidified as opposed to being naturally acidic could not be fully established by palaeolimnological methods in the years running up to the formation of the Network.

In the late 1980s, following the United Kingdom's decision to sign the UNECE Convention on Long-Range Transboundary Air Pollution (UNECE-CLTRAP), a detailed assessment of the extent of surface water acidification across the United Kingdom was carried out using a 'critical loads' approach (Henriksen et al., 1992; Nilsson and Grennfelt, 1988) as required by the Convention. For the United Kingdom, this necessitated the first ever systematic sampling of freshwater chemistry across the country on a 10-km grid square basis (Kreiser et al., 1993) and the national mapping of surface waters where acid deposition exceeded the critical load (Critical Loads Advisory Group (CLAG), 1995). The study clearly indicated significant regions in both the Pennines and the NYM where the critical load was exceeded, and for the first time provided evidence that the naturally acidic surface waters in both these regions had probably become even more acidic as a result of their exposure to acid deposition. Further evidence for the likely impact of acid deposition on surface waters in the NYM was provided by Evans et al. (2014) who, in 2005, conducted a detailed hydrochemical survey of 51 water bodies in the region, including a small number of moorland pools (Figure 1). Evans et al. (2014) showed that many of the streams and pools sampled, especially those with afforested catchments, were indeed exceptionally acidic and, on the basis of sulphur isotope analysis, concluded that the high non-marine sulphate concentrations in the water were derived from fossil-fuel combustion.

One of the surprising findings of the study, however, was that there was little evidence of recovery from acidification by 2005 , despite the major reduction in acid deposition that has taken place over the last 30 years as reflected by strongly decreasing trends in $\mathrm{S}$ and $\mathrm{N}$ deposition at the High Muffles deposition monitoring site within the NYM (Figure 1). The basis for this finding was a 20-year record of fortnightly $\mathrm{pH}$ measurements from Danby Beck (Figure 1), a headwater stream in the NYM, compiled by a local volunteer group (Chadwick, 2001; Evans et al., 2014). The lack of evidence for recovery shown by this time-series re-opened the question whether these very acidic waters were naturally highly acidic or whether they had been acidified by pollutant acid deposition but had not begun to recover in contrast to evidence for acidification recovery elsewhere in the United Kingdom (cf. Battarbee et al., 2014; Monteith et al., 2014).

These observations highlighted the need to find one or more sites in the region that might contain a recent sediment record and provide a longer temporal perspective on the Danby Beck timeseries. Following Evans' (personal communication, 2006) suggestion we selected Grey Heugh Slack, a moorland pool with a chemistry similar to that of Danby Beck (Evans et al., 2014), to assess its potential for palaeolimnological analysis. This paper describes a multi-proxy investigation of a sediment core from the site designed to provide a record of contamination by air pollutants in the region and to assess the acidification status of the site.

\section{Site}

Grey Heugh Slack (Figure 1) lies on the NYM in northeast England at an altitude of $195 \mathrm{~m}$ near the edge of Fylingdales Moor (Lat: $54.409743 \mathrm{~N}$, Long: 0.601496E). It is situated downwind of several major power stations located in Yorkshire, principally Drax, Ferrybridge and Eggborough, and it lies close to the heavy industry area of Teesside to the north.

It is a small dystrophic pool, 1.3 ha in area, set in a small, lowrelief, poorly defined catchment dominated by blanket peats with vegetation consisting mainly of Calluna vulgaris and associated moorland sedges and bryophytes. The pool is fringed by Juncus effusus that forms a continuous stand around its perimeter. There are no apparent surface inflows, and the pool drains to the southwest through an outflow choked with Juncus. The water at the time of coring in October 2006 was $65 \mathrm{~cm}$ deep at the deepest point close to the western shore. The bed of the pool comprises 
Table I. Principal characteristics of Grey Heugh Slack: Morphometric data including the Water Body identification number (WBID) from the UK Lakes Inventory (Bennion et al., 2005) and chemical data from Evans et al. (2014) based on a spot sample from March 2005.

\begin{tabular}{ll}
\hline WBID & 29245 \\
Altitude & $195 \mathrm{~m}$ \\
Surface area & $1.3 \mathrm{ha}$ \\
Catchment area & $34.5 \mathrm{ha}$ \\
$\mathrm{pH}$ & 4.1 \\
Alkalinity & $-84 \mu \mathrm{eq} \mathrm{L}-1$ \\
ANC & $-119 \mu \mathrm{eq} \mathrm{L}-1$ \\
Aluminium & $220 \mu \mathrm{eq} \mathrm{L}-1$ \\
Calcium & $35 \mu \mathrm{eq} \mathrm{L}-1$ \\
Sulphate & $157 \mu \mathrm{eq} \mathrm{L} \mathrm{L}^{-1}$ \\
Nitrate & $1 \mu \mathrm{eq} \mathrm{L}-1$ \\
DOC & $7.6 \mathrm{mg} \mathrm{L}^{-1}$ \\
\hline
\end{tabular}

sub-rounded stones in the shallow littoral zone with a small area of peaty sediment confined to the deepest water.

Summary data from a sample taken for water chemistry taken in 2005 are shown in Table 1. The $\mathrm{pH}$ of the pool was 4.1. Samples for diatom analysis taken at the time of coring in 2006 showed that the overwhelmingly dominant taxon present was Eunotia exigua (Bréb) Rabh., a diatom typical of highly acidic environments.

The pool is believed to occupy the site of a peat cutting abandoned in late 18th century (see below). It is shown on the first Ordnance Survey map for the area of 1853 , and ${ }^{210} \mathrm{~Pb}$ dating, by extrapolation, indicates the presence of early 19 th century sediments (see below and supplementary material, available online).

\section{Methods}

\section{Coring}

The location of the zone of sediment accumulation in the deepest water of the pool was identified by probing with a metal rod. A transect was then set up by fixing a rope across the site along the line of maximum sediment thickness, and cores were taken along the transect line using a piston corer. All but the core with the longest record were discarded. The core retained was $41 \mathrm{~cm}$ long and was collected from a site close to the western edge of the pool. It was given the code GHEU1 and returned to the UCL laboratory intact for extrusion.

\section{Lithostratigraphy}

In the laboratory, the sediment was extruded vertically and sliced at $0.5 \mathrm{~cm}$ intervals. Sediment moisture content (DW) was derived after drying at $105^{\circ} \mathrm{C}$ for $12 \mathrm{~h}$, wet density was measured by weighing a known volume of wet sediment in a brass vial and loss on ignition (LOI) was calculated after combusting a known weight of dry material in a furnace at $550^{\circ} \mathrm{C}$.

\section{Radiocarbon dating}

Only material from the highly organic peat zone of the core was radiocarbon-dated. Bulk samples were pre-treated using a standard acid-alkali-acid method (De Vries and Barendsen, 1952) and dried at $60^{\circ} \mathrm{C}$ overnight. The dried samples were sealed into pre-combusted quartz tubes with an excess of copper oxide $(\mathrm{CuO})$ and a silver strip, sealed under vacuum and combusted to carbon dioxide $\left(\mathrm{CO}_{2}\right)$ which was converted to graphite on an iron catalyst using the zinc reduction method (Slota et al., 1987). The ${ }^{14} \mathrm{C} /{ }^{12} \mathrm{C}$ and ${ }^{13} \mathrm{C} /{ }^{12} \mathrm{C}$ ratios were measured by accelerator mass spectrometry (AMS) at the ${ }^{14} \mathrm{CHRONO}$ Centre, Queen's University Belfast. The sample ${ }^{14} \mathrm{C} /{ }^{12} \mathrm{C}$ ratio was background corrected and normalised to the HOXII standard (SRM 4990C; National Institute of Standards and Technology (NIST)). The radiocarbon ages were corrected for isotope fractionation using the AMS-measured $\delta^{13} \mathrm{C}$ which accounts for both natural and machine fractionation. The standard deviation includes a laboratory error multiplier of 1.2 based on reproducibility of secondary standards. The radiocarbon age and one standard deviation were calculated using the Libby half-life of 5568 years following the methods of Stuiver and Polach (1977). Radiocarbon ages were calibrated with CALIB 7.0.2 using the IntCal13 calibration curve (Reimer et al., 2013).

\section{${ }^{210} \mathrm{~Pb}$ and ${ }^{137} \mathrm{Cs}$ dating}

Dried sediment samples from the upper unit $(0-14 \mathrm{~cm})$ of the GHEU1 core were analysed for ${ }^{210} \mathrm{~Pb},{ }^{226} \mathrm{Ra},{ }^{137} \mathrm{Cs}$ and ${ }^{241} \mathrm{Am}$ by direct gamma assay in the UCL Environmental Radiometric Facility using an ORTEC HPGe GWL series well-type coaxial low-background intrinsic germanium detector. Lead-210 was determined through its gamma emissions at $46.5 \mathrm{keV}$ and ${ }^{226} \mathrm{Ra}$ by the 295 and $352 \mathrm{keV}$ gamma rays emitted by its daughter isotope ${ }^{214} \mathrm{~Pb}$ following 3-week storage in sealed containers to allow radioactive equilibration. Caesium-137 and ${ }^{241} \mathrm{Am}$ were measured by their emissions at 662 and $59.5 \mathrm{keV}$, respectively (Appleby et al., 1986). The absolute efficiencies of the detector were determined using calibrated sources and sediment samples of known activity. Corrections were made for the effect of selfabsorption of low-energy gamma rays within the sample (Appleby et al., 1992).

\section{Trace metals and geochemical element analyses}

For $\mathrm{Hg}$ analysis, $0.2 \mathrm{~g}$ of freeze-dried sediment was weighed into a 50-mL polypropylene DigiTUBE (SCP Science), to which $8 \mathrm{~mL}$ aqua regia was then added (Lomonte et al., 2008). This was gradually heated on a hot plate to $100^{\circ} \mathrm{C}$ to avoid violent reaction and then digested for a further $2 \mathrm{~h}$. After cooling, the digested solution was diluted to $50 \mathrm{~mL}$ with distilled deionised water. Mercury concentrations in digested solutions were measured by cold vapouratomic fluorescence spectrometry (CV-AFS; PS Analytical Millennium Merlin 1631) following reduction with $\mathrm{SnCl}_{2}$. Standard solutions and quality control blanks were measured every five samples to monitor measurement stability. Standard reference material stream sediment GBW07305 (supplied by the National Research Center for Certified Reference Materials (NRCCRM, Beijing; certified $\mathrm{Hg}$ value $100 \pm 10 \mathrm{ng} \mathrm{g}^{-1}$; measured mean value $100.3 \mathrm{ng} \mathrm{g}^{-1}$ with relative standard deviation $4.5 \mathrm{ng} \mathrm{g}^{-1}$ ) and sample blanks were digested with every 20 samples.

For other heavy metals and geochemical elements, sediment samples were analysed by using a Spectro XLAB2000 x-ray fluorescence (XRF) spectrometer. Freeze-dried sediments were crushed to a fine powder in their original sample bags. Approximately $1 \mathrm{~g}$ of this material was placed in nylon cups with a base of prolene foil ( $4 \mu \mathrm{m}$ thickness) and slightly pressed with a pestle. Reference sediment samples (Buffalo River Sediment, NIST RM8704; Canadian Certified Reference Materials Project (CCRMP) - LKSD-2) were included in each sample batch run (18 samples) to identify any machine drift error and assess measurement accuracy. Recovery ranges for the reported elements are within $95-105 \%$.

\section{Stable isotopes}

Stable isotope analysis was conducted only on samples from the upper zone. A sample weight of approximately 4-6 mg was used in a Flash Elemental Analyser (1112 series; Thermo-Finnigan) 
coupled to a Finnigan Delta V isotope ratio mass spectrometer (Thermo-Finnigan) at the UCL-Bloomsbury Environmental Isotope Facility (BEIF) laboratory. Three-point calibrations were carried out using certified standards analysed with the samples (IAEA-N1, IAEA-N2 and USGS40). The percentage of organic nitrogen was calculated based on an alanine standard. Stable isotope values are reported in standard delta notation relative to the international air standard.

\section{Magnetic measurements}

Only samples from the upper zone were used for magnetic measurements. The combination of low sample mass, high organic matter content and low concentrations of magnetic minerals precluded reliable susceptibility measurements. Anhysteretic remanences (ARMs) were grown using a DTECH demagnetiser in a peak alternating field of $100 \mathrm{mT}$, with a steady DC biasing field of $0.1 \mathrm{mT}$, and expressed as the susceptibility of ARM $\left(\chi_{\text {ARM }}\right)$ by dividing the ARM by the DC biasing field. This measurement is particularly sensitive to the concentration of ferrimagnetic minerals in the stable single domain (SD) size range. Isothermal remanences were grown using a MMPM5 Pulse Magnetiser. Saturation isothermal remanent magnetisation (SIRM) was generated in a 1-T field after which the samples were reverse magnetised in a succession of increasing DC fields $(-20,-40,-100$ and $-300 \mathrm{mT})$.

\section{Spheroidal carbonaceous particles}

Spheroidal carbonaceous particle (SCP) analysis of samples from the upper zone of the core involved sequential treatments of nitric, hydrofluoric and hydrochloric acids to remove organic, siliceous and carbonate fractions, respectively, resulting in a suspension of mainly carbonaceous material in water (Rose, 1994). A known fraction of this suspension was then evaporated onto a coverslip, mounted onto a glass slide, and the number of SCPs was counted using a light microscope at $400 \times$ magnification. Standard criteria for SCP identification were followed (Rose, 2008). SCP concentrations were calculated in units of 'number of particles per gram dry mass of sediment' $\left(\mathrm{gDM}^{-1}\right)$ and SCP fluxes as 'number of particles per $\mathrm{cm}^{2}$ per year' $\left(\mathrm{cm}^{-2} \mathrm{yr}^{-1}\right)$. Analytical blanks and SCP reference material (Rose, 2008) were included with sample digestions. The detection limit for the technique is typically less than $100 \mathrm{gDM}^{-1}$, and calculated concentrations generally have a precision of $c . \pm 45 \mathrm{gDM}^{-1}$.

\section{Pollen analysis}

Pollen preparation and identification (at 400×) followed standard procedures (Moore et al., 1991). Pollen counts of 400 grains including spores were made. Samples in the peat section of the core were dominated by Alnus, Corylus and Betula. These pollen types have been excluded from tree pollen sums in more detailed landscape change studies from the area (e.g. Innes et al., 2010; Innes and Simmons, 2000) but are included here.

\section{Diatom analysis}

Diatom analyses followed standard protocols (Battarbee et al., 2001). Samples were prepared using $30 \%$ hydrogen peroxide to destroy organic matter, and microscope slides were prepared using Naphrax as a mounting medium. Counts of approximately 300 valves per sample were made using light microscopy at $1000 \times$ magnification. Taxonomy is based on SWAP guidelines (Stevenson et al., 1991). Changes in the quality of preservation were assessed using the diatom dissolution index (DDI) (Ryves et al., 2009) but only applied to Frustulia rhomboides var. saxonica, a diatom found at every level in the core. Diatom-inferred $\mathrm{pH}$ values were derived using the SWAP training set (Birks et al., 1990).

\section{Results \\ Lithostratigraphy}

The dry weight (DW) and LOI results clearly indicate three distinctly different lithostratigraphic zones in the core (Figure 2). The basal samples below $36 \mathrm{~cm}$ are a mixture of organic and mineral material, probably representing the soil surface above which blanket peats $(36-14 \mathrm{~cm})$ were formed. The peats above are almost entirely organic in composition with LOI values of c. $95 \%$. The upper levels of the peat $(19-14 \mathrm{~cm})$ are slightly more variable, the organic content drops to between $88 \%$ and $91 \%$ and the DW values increase slightly. Above the peats, there is a sharp discontinuity: the upper $14 \mathrm{~cm}$ are peaty muds with a high organic matter content rising from $c$. $55 \%$ to almost $80 \%$ at the sediment surface.

The threefold distinction shown by the LOI data is reflected by the XRF data on major elements (Figure 2), with relatively high $\mathrm{Al}, \mathrm{Si}, \mathrm{K}, \mathrm{Ti}$ and $\mathrm{Zr}$ values characterising the basal and uppermost zones, reflecting the inclusion of mineral material from lithospheric sources, separated by the middle section of almost pure peat where these mineral elements occur in very low abundance. Calcium appears to be the exception (Figure 2), but the relatively high concentration data are the result of the reciprocal relationship of $\mathrm{Ca}$ to other elements. The similarity of the peaty soils at the base of the core and the peaty sediments at the top, with respect to both organic matter and major element composition, indicate common lithospheric sources.

\section{Chronology and sediment accumulation rates}

On the basis of the lithostratigraphy and the pollen analytical data (see below), five samples from the peat section (zone 2) including the highest sample $(14-15 \mathrm{~cm})$ immediately below the basal pool sediment sample were radiocarbon-dated (see Supplementary Table 1, available online). The Bayesian age-modelling software Bacon (Blaauw and Christen, 2011) and the northern hemisphere terrestrial calibration curve IntCal13 (Reimer et al., 2013) were used to generate an age-model for the two lower units (Supplementary Figure 1, available online). A chronology for the upper unit was established from ${ }^{210} \mathrm{~Pb}$ and ${ }^{137} \mathrm{Cs}$ dating using the CRS dating model (Appleby and Oldfield, 1978) (see Supplementary Figures 2 and 3, available online).

The radiocarbon data provide an age estimate for the basal sediments of the core $(41 \mathrm{~cm})$ of approximately $8000 \mathrm{cal}$. BP (calendar years before $\mathrm{AD} 1950$ ) and an estimate for the boundary between the peat sequence and the pool sediments $(14 \mathrm{~cm})$ of approximately $6700 \mathrm{cal}$. BP.

For the pool sediments, ${ }^{210} \mathrm{~Pb}$ dating (Supplementary Figures 2 and 3, available online) indicates a date of $\mathrm{AD} 1868 \pm 20$ years for the mid-point of the $12-13 \mathrm{~cm}$ sample, the lowest sample with dateable sediment. A further $1 \mathrm{~cm}$ of mud lies beneath this sample before the upper boundary with the peat. On the assumption of a constant accumulation rate of $0.19 \mathrm{~mm} \mathrm{yr}^{-1}$ at this depth, the calculated date for the origin of the pool is $\mathrm{AD} 1789$ or, given the uncertainties in dating, late 18 th century.

\section{Pollen data}

The pollen data (Figure 3) show the clear discontinuity between the top of the middle and upper zones and a sharp transition between the lower two zones. The basal zone from 41 to $32 \mathrm{~cm}$ is dominated by Pinus, Betula and Corylus pollen, although Quercus and Ulmus are also present. Non-arboreal pollen taxa are almost completely lacking. The middle zone from 32 to $14 \mathrm{~cm}$ is 


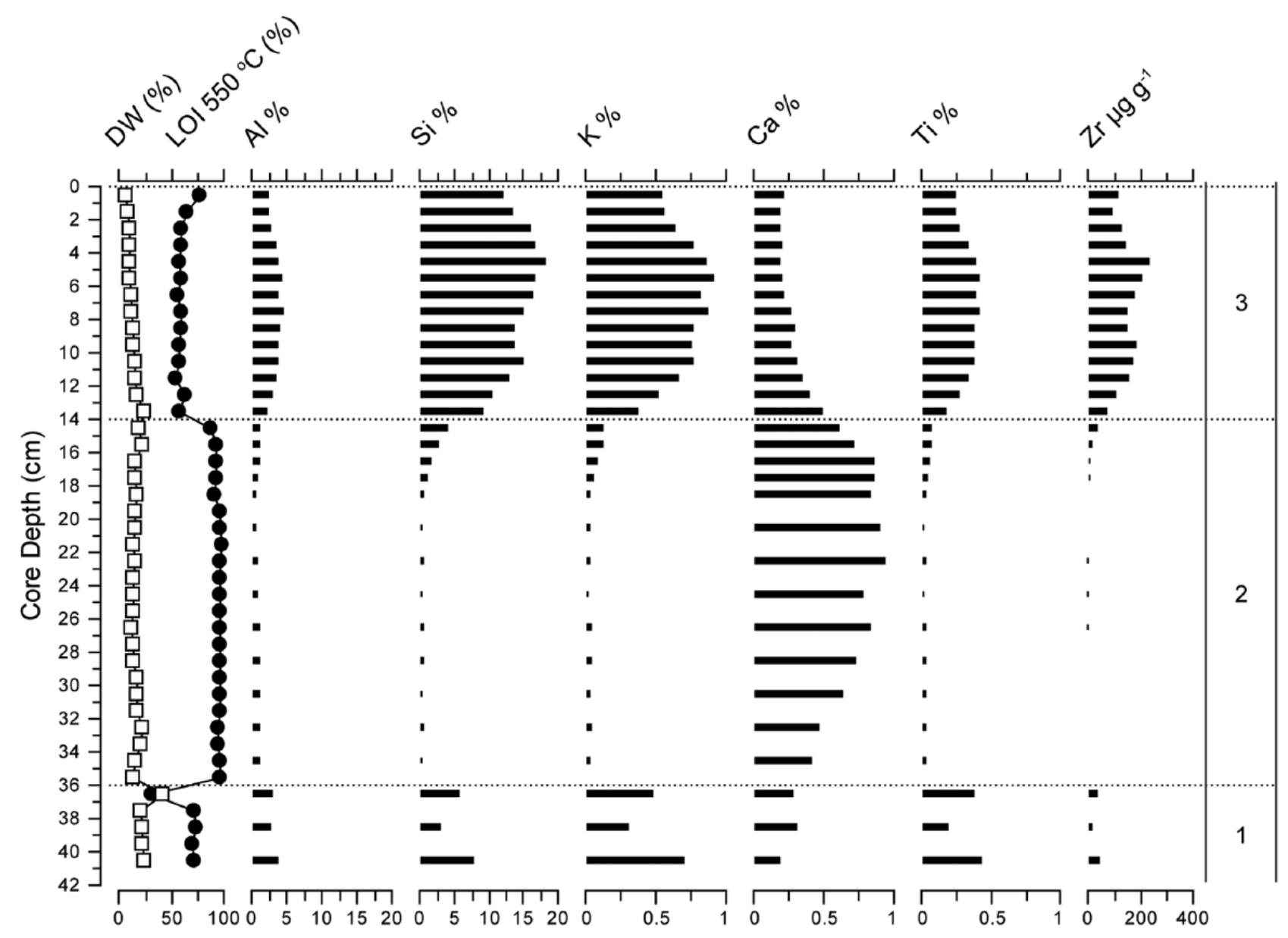

Figure 2. Lithostratigraphy of core GHEUI from Grey Heugh Slack showing the threefold division into a (I) peaty soil, (2) peat and (3) peaty sediment with data for dry weight (DW), loss on ignition (LOI) and major element geochemistry (\% dry mass).

also dominated by forest taxa, but Pinus is absent and Alnus is the dominant pollen type. Betula and Corylus are present but are relatively less important than in the previous period. The switch from a Betula/Pinus to an Alnus dominated assemblage centres on a median age of $7630 \mathrm{cal}$. BP, the estimated date for $32 \mathrm{~cm}$ midway between the two pollen samples at 30 and $34 \mathrm{~cm}$ that lie on either side of the pollen boundary.

The upper zone of the core $(14-0 \mathrm{~cm})$ has a significantly different pollen assemblage from the previous two zones. Although tree pollen, including Alnus, Betula, Pinus, Quercus, Ulmus, Tilia, Fraxinus and Acer, is well represented, the pollen assemblage also includes significant quantities of non-arboreal pollen typical of open landscape conditions. This includes ericaceous pollen (especially Calluna vulgaris), and Cyperaceae, representative of moorland vegetation, along with Gramineae (Poaceae), Plantago lanceolata and Rumex acetosella, taxa typical of pastureland. The relatively high abundance of pine pollen towards the top of the core probably reflects the presence of post-WW2 conifer plantations in the vicinity of the site.

\section{Air pollutants}

The stratigraphic record of air pollutants recorded by Grey Heugh Slack pool sediments $(0-14 \mathrm{~cm})$ is shown in Figure 4. It includes heavy metals, SCPs, $\delta^{15} \mathrm{~N}$ and magnetics.

Profiles for trace metals and the metalloid As (Figure 4) have somewhat different temporal patterns. $\mathrm{Hg}$ has relatively high concentrations in the lower zones but increases markedly in the uppermost zone, whereas $\mathrm{Pb}, \mathrm{Zn}$ and As values are either very low or below detection in the lowest two zones but high in the top zone. They follow a similar pattern, rapidly increasing from low values across the boundary with the middle zone at $c .14 \mathrm{~cm}$ to sustained high values towards the surface in the case of $\mathrm{Hg}, \mathrm{Pb}$ and $A s$ or to a maximum at $c .10 \mathrm{~cm}$ followed by a rapid decline in the case of $\mathrm{Zn}$. The behaviour of $\mathrm{Zn}$ is different from that of the other metals possibly reflecting its release from the sediments as the lake water became increasingly acidic (see below).

The first presence of SCPs is recorded in the decades prior to the mid-19th century which is a little earlier than observed at other sites in the United Kingdom (Figure 4). SCP accumulation rates increase steadily to the mid-20th century followed by rapid increase through to a peak in the 1980s in reasonable agreement with other SCP sediment records from lakes in the northeast of England (Rose and Appleby, 2005).

Stable isotope $\delta^{15} \mathrm{~N}$ values (Figure 4) show a substantial decrease by $\sim 1.6 \%$ between about 8.5 and $5.5 \mathrm{~cm}$ (1940-1970). There was also a significant increase in organic nitrogen by $0.5 \%$ at the same time (two-sample $t$-test, $p=0.001$; not shown).

The results of $\chi_{\mathrm{ARM}}$ and IRM measurements on samples from the uppermost zone of the core including the IRM remaining unreversed in a back-field of $-100 \mathrm{mT}$ are shown in Figure 4. All the properties measured show increasing values from the base of the upper zone to the surface. In the case of $\chi_{\mathrm{ARM}}$, the increase is steepest immediately below the surface. This feature is absent from all the components of the IRM measured. There are no significant changes in high reverse field percentage ('S') values.

\section{Diatoms}

Diatoms were absent from the lower part of the core but present in the upper $15 \mathrm{~cm}$ (Figure 4). Only the upper $14 \mathrm{~cm}$ belong to the upper zone characterised by lake sediments, so the diatom record 


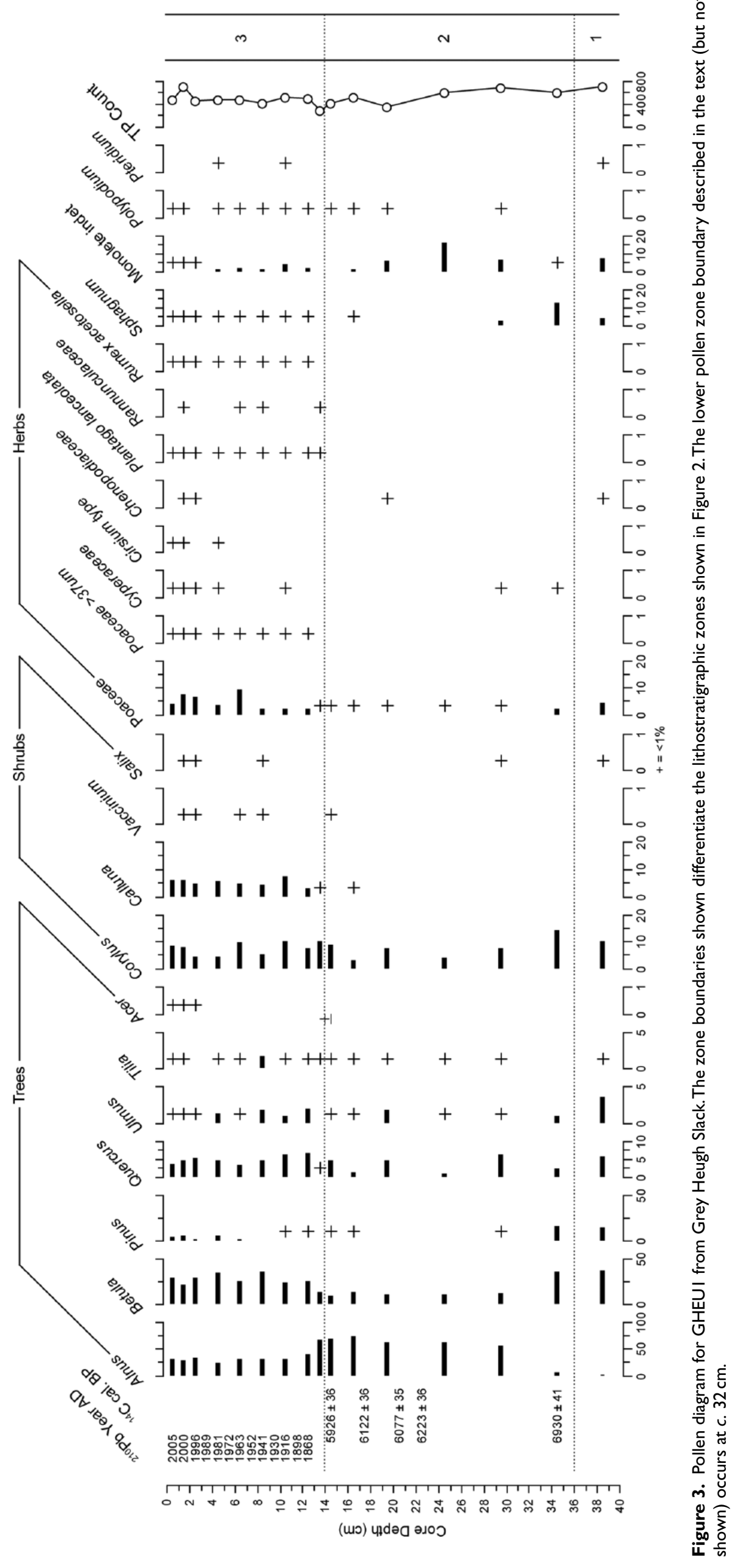




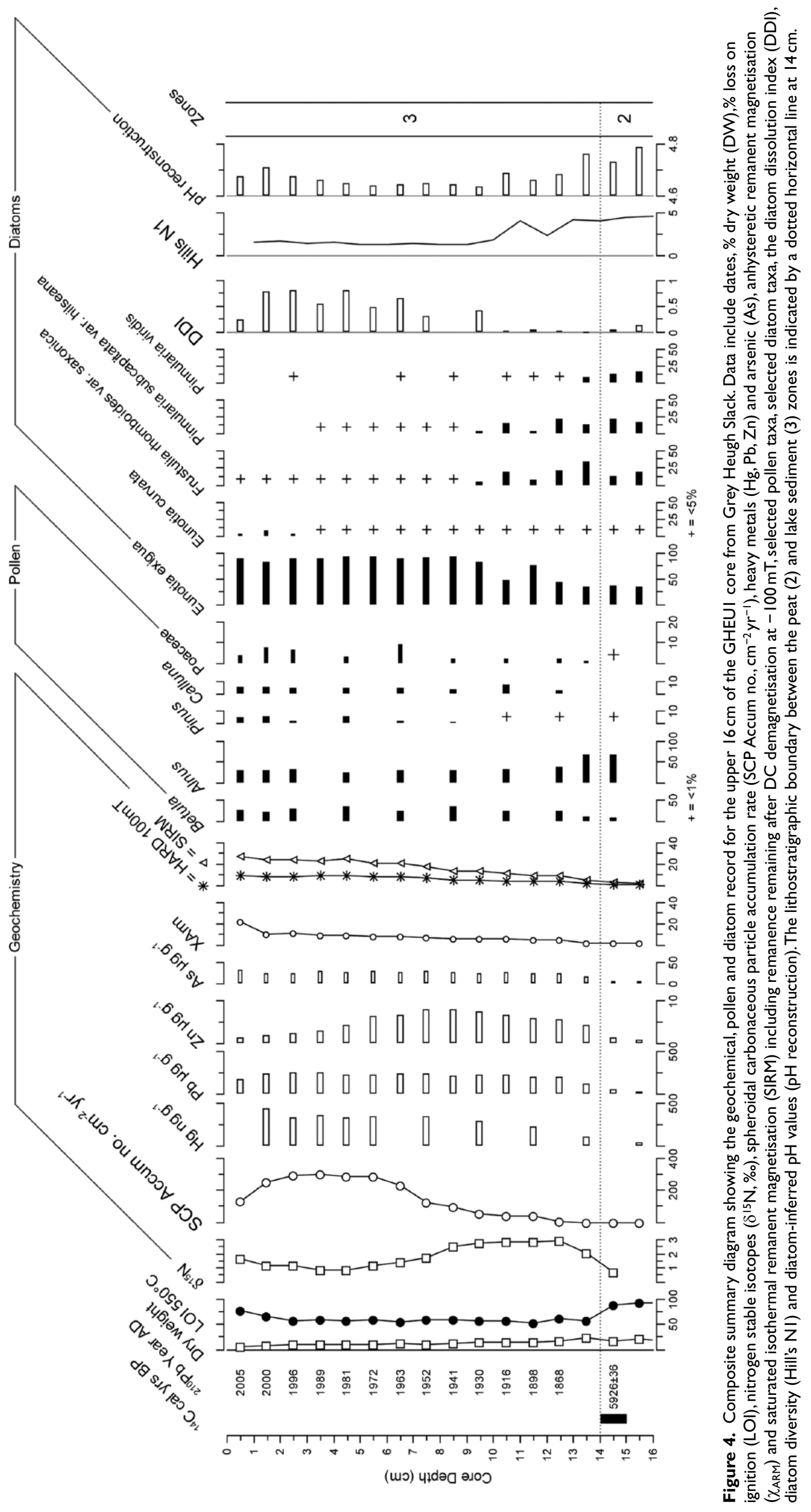


extends down into the upper part of the peat sequence (cf. Figure 2 ), possibly reflecting the growth of diatoms on the wet peat surface. There is a clear change in the composition of the diatom assemblage between 10 and $9 \mathrm{~cm}$. Below this, the flora consists of Eunotia exigua (Bréb) Rabh., Frustulia rhomboides var. saxonica (Rabh.) de Toni, Pinnularia subcapitata var. hilseana (Janisch) O.Müller and Pinnularia viridis (Nitzsch) Ehrenberg in approximately equal proportions, and above the assemblage is completely dominated by Eunotia exigua, although Frustulia rhomboides var. saxonica remains present throughout. The DDI data (Figure 4) for Frustulia show, despite its very low relative abundance in the upper $9 \mathrm{~cm}$, it is considerably better preserved than in the $16-10 \mathrm{~cm}$ section indicating that its decline, and the increase in Eunotia exigua, cannot be explained by changes in preservation. The diversity values, also shown in Figure 4, decrease between 10 and $9 \mathrm{~cm}$.

All taxa in the assemblage are acid-tolerant ones. Eunotia exigua in particular is found in very acidic freshwater conditions, and its increase in abundance relative to other taxa is the reason for the decrease in diatom-inferred $\mathrm{pH}$ between $c .10$ and $9 \mathrm{~cm}$ (Figure 4). However, the magnitude of the decrease in $\mathrm{pH}$ indicated $(<\mathrm{pH} 0.2)$ is probably a significant under-estimate (see below).

\section{Discussion}

\section{Origins and history of the pool}

Shallow pools commonly occur in the moorlands of upland Britain. Their origins are diverse, few are natural. Many have low earth and stone dam faces reflecting their origin as artificial impoundments. Grey Heugh Slack is different. It occupies a shallow hollow in the peat and there are no signs of any structures that might suggest it was deliberately created to store water. The evidence from the sediment record described here suggests that it may be an abandoned peat cutting. Peat cutting was common in the NYM over many centuries, with members of the local population (the commoners) having grazing, turbary and stone sourcing rights on the moors (Cookson, 2009). Foulsike Farm, the farm closest to Grey Heugh Slack, had such rights as well as direct access to the moor close to the site (Figure 1).

The sediment record suggests the pool has been in existence for approximately the last 220 years. The sediments formed during the pool stage lie unconformably on the peat as seen from the LOI data (Figure 2). The top of the peat sequence dates to approximately $6740 \mathrm{BP}$. If the base of the pool sediments is taken as 220 $\mathrm{BP}$, the hiatus between the two zones is 6520 years. We can then suppose that peat cutting has removed all the peat in the hollow except for approximately $20 \mathrm{~cm}$ (the depth of the peat sequence in the core) in the area around the core site.

The pollen assemblage data from the pool sediments (upper $14 \mathrm{~cm}$ ) closely reflect the nature of the vegetation in the vicinity of the pool at the present day including pine pollen from conifer plantations, ruderal taxa indicative of agriculture and Calluna from the adjacent moorland managed for sheep grazing and grouse shooting.

The pollen record from the peat section below shows, as expected from the radiocarbon dating, an assemblage almost completely dominated by early to mid-Holocene forest and shrub taxa, clearly pre-dating Neolithic forest clearance and providing no evidence of early agriculture. The assemblage is almost identical to other sites in the NYM of the same age (e.g. Atherden, 1979; Innes and Simmons, 2000; Simmons and Cundill, 1974; Turner et al., 1993). The upper part of the peat sequence is consistent with the proposal of Innes et al. (2010) of a late Mesolithic forested landscape dominated by Quercus with an understorey of Betula and Corylus.

At the base of the peat sequence, there is an abrupt transition to the lowermost $c .5 \mathrm{~cm}$ of the core which is high in organic matter and has a major element geochemistry very similar to the pool sediments of the uppermost zone. It has a relatively high content of Al, Si and K (Figure 2), indicating the presence of alumino-silicate minerals. The material in this lowest zone was not directly dated, but extrapolation of the radiocarbon age-model suggests it can be dated to approximately $7500-8000$ cal. BP, in agreement with the age indicated by the pollen assemblage that is dominated by Pinus and Betula. As the corer could not be pushed downwards beyond the base of this zone, it is probable from its mineralogy and organic matter content that it represents the surface horizon of a forest soil of Boreal age above which the blanket mire began to form through paludification at the beginning of the Atlantic period (cf. Moore, 1975; Ruppel et al., 2013).

In summary, the present-day pool is thought to have its origin as a peat cutting abandoned in the late 18th century. Sediments have accumulated in the pool over the last 220 years, thereby providing a record of environmental change from the beginning of the Industrial Revolution to the present day. The excellence of the record suggests that similar moorland pools in the UK uplands may also have conformable sediments and should not therefore be ignored in the search for useful records of environmental change in regions where natural lakes are lacking.

\section{Record of contamination by atmospheric pollutants}

Although the recent sediment accumulation rate for Grey Heugh Slack is quite low at $c .1 \mathrm{~mm} \mathrm{yr}^{-1}$, the upper $14 \mathrm{~cm}$ of sediment in the core contains an excellent record of airborne pollutants, most probably because there has been very little input of particulate material from the catchment to distort the atmospheric signal. There are no discrete surface inflows. Water enters the pool via seepage through the surrounding mire. Consequently, the record of heavy metals, $\delta^{15} \mathrm{~N}, \mathrm{SCPs}$ and magnetics (Figure 4), that can be used to track trends in air pollution over the last 150 years or more can be assumed to be one that directly reflects deposition to the pool and adjacent mire surfaces.

The SCP accumulation rate profile (Figure 4) is typical of many described for lakes in the United Kingdom (Rose and Appleby, 2005) which show low accumulation rates from the mid-19th century, rising gradually in the first part of the 20th century and then rapidly in the 1950 s and 1960 s to a peak before decreasing to the present day. The rapid increase is generally attributed to the elevated demand for electricity, and the introduction of fuel-oil as a means to generate it, following WW2. From the peak, the accumulation rate (Figure 4) declines such that the surface values (2006) are the lowest since the 1950s. This marked reduction is because of the introduction of successively more rigorous control legislation and the retrofitting of particle-arrestor technology (e.g. electrostatic precipitators) to fossil-fuelled power stations, increased combustion efficiency, the switch to fuels such as natural gas and, in some regions, the decline in heavy industry in the United Kingdom (Rose, 2001). In terms of absolute concentrations and accumulation rates, while SCP contamination of Grey Heugh Slack has been significantly higher than many areas of the United Kingdom, probably reflecting the proximity of major power stations upwind, peak SCP concentrations and accumulation rates are considerably lower at the site than regions such as Galloway in southwest Scotland (Rose, 2001).

The geochemical data for the core show that the air pollutants most commonly associated with fossil-fuel burning such as $\mathrm{Hg}$, $\mathrm{Pb}$ and As increase gradually during the 19th and early 20th century following the pattern shown elsewhere in upland regions of the United Kingdom (e.g. Rippey, 1990). However, concentrations of $\mathrm{Hg}, \mathrm{Pb}$ and $\mathrm{As}$ in the sediment might be expected to decrease towards the sediment surface as emissions have declined significantly in the United Kingdom over recent decades (National 
Atmospheric Emissions Inventory, 2014), but they remain high right up to the present day (even increasing, if corrected for changes in sediment accumulation rate), probably indicating a continuous release of contaminants from the surrounding peatland. This lack of response to emission reduction has been noted before (e.g. Rose et al., 2012; Yang et al., 2002), but these earlier studies related the remobilisation of trace metals predominantly to the erosion of catchment soils (Rose et al., 2012). Here, where there is no evidence of soil erosion, the metals are more likely to be transported in association with dissolved rather than particulate organic carbon (cf. Weng et al., 2002), an inference supported by the lack of coupling between the heavy metal and SCP records.

There is a growing literature arguing that changes in $\delta^{15} \mathrm{~N}$ in the sediments of remote lakes can be used to indicate trends in the deposition of $\mathrm{N}$ released into the atmosphere by human activity, especially from fossil-fuel combustion (e.g. Holtgrieve et al., 2011). The characteristic depletion by $c$. $1-3 \%$ observed in such lakes has also been described elsewhere from upland lakes in the United Kingdom (Curtis and Simpson, 2011). The record from Grey Heugh Slack closely matches these records in both timing and magnitude. The sharp drop in values occurs between $c .9$ and $6 \mathrm{~cm}$ depth in the core, dating to $c$. 1935-1965. The decrease correlates closely with the steep rise in SCPs (see below) and the known major increase in the combustion of fossil fuels at this time in the United Kingdom and more widely in Europe, including the record in Greenland ice cores (Hastings et al., 2009). Diagenesis or a change in nutrient limitation from nitrogen to phosphorus could affect fractionation processes resulting in decreasing $\delta^{15} \mathrm{~N}$ up the core. Diagenetic effects should be most pronounced in approximately the first 30 years following sedimentation (Gälman et al., 2009). This encompasses the top $5 \mathrm{~cm}$ of the core and thus does not coincide with the timing of the isotopic shift. A change in nutrient limitation at the site from nitrogen to phosphorus could lead to lower $\delta^{15} \mathrm{~N}$ by reducing fractionation during algal uptake and use of inorganic nitrogen. However, this seems unlikely given the very acidic conditions of the site, since phosphorus can be bound by aluminium colloids and made less available at sites with such low $\mathrm{pH}$ values (Kopáček et al., 2005). Overall, the timing and characteristic pattern of the shift in $\delta^{15} \mathrm{~N}$ within the core appear consistent with inputs from atmospheric nitrogen deposition.

In the absence of catchment inputs, the Grey Heugh Slack mineral magnetic record can be assumed to be dominated by magnetic particles deposited from the atmosphere, especially by those produced by coal combustion, iron and steel manufacture and metal smelting (Oldfield et al., 1983; Oldfield et al., this volume). However, the steep increase in $\chi_{\mathrm{ARM}}$ values at the top of the core (Figure 4), not reflected in any component of the IRM, probably results from early dissolution of SD grains of biogenic magnetite produced in situ by magnetotactic bacteria. Moreover, the $\chi_{\mathrm{ARM}}$ measurements alone do not preclude the possibility that the increase in both the $\chi_{\text {ARM }}$ and SIRM values may have been influenced by progressive dissolution at lower depths. For this reason, the curve for magnetically 'hard' IRM has been included in Figure 4. Remanences remaining after demagnetisation in reverse fields above $100 \mathrm{mT}$ are unlikely to be significantly influenced by ferrimagnetic grains and reflect the changing concentration of imperfect anti-ferromagnetic minerals, in this case, predominantly haematite. The fact that the $-100 \mathrm{mT}$ curve is parallel to SIRM steadily increasing from the base and peaking at the surface indicates that the latter is likely to be a reliable measure of allochthonous input rather than in situ bacterial activity. The inference is reinforced both by the lack of any changes in high reverse percentage ('S') values and by the quotient $\chi_{\mathrm{ARM}}$ /SIRM values. Omitting the basal and surface samples, these range between 0.36 and $0.55 \times 10^{-3} \mathrm{~mA}^{-1}$. These are below those typical for bacterial magnetite by a factor of 5 (Oldfield, 2013). We therefore conclude that the underlying increase in SIRM is a faithful reflection of trends in the deposition of particulates indistinguishable magnetically from inorganic fly-ash.

In summary, there are multiple independent lines of evidence from the Grey Heugh Slack sediment record that indicate a long history of atmospheric pollution at the site similar to the record from other lakes in the United Kingdom lying within the hinterland of pollutant emissions from fossil-fuel burning. The contaminant record not only indicates trends in air pollutants, some of which are directly toxic, but also provides proxy evidence for trends in $\mathrm{S}$ and $\mathrm{N}$ deposition associated with the emissions of acidic gases.

\section{Evidence of acidification}

The contaminant record is clear. What is less clear is the extent to which Grey Heugh Slack and other similar acidic waters in the NYM (Evans et al., 2014) have been acidified, and altered ecologically, by their exposure to acid deposition over the last 150 years. In the absence of any long-term biological records from this region, palaeoecological methods offer the only means to provide the definitive evidence needed, yet perfect sites for such studies, that is, natural, relatively deep, clearwater lakes with a long sediment record, that typically occur in the more strongly glaciated regions of the United Kingdom are lacking here. Grey Heugh Slack has few of these ideal attributes: it is artificial, very shallow and naturally dystrophic, but it does have a good sediment record that, fortuitously, extends just far enough back in time to span the 150 -year or so time period of major interest, and it contains a diatom record, albeit rather impoverished and dissolved, that can be used to infer changes in acidity through time.

The extent of acidification indicated by the diatom flora, however, is not easy to judge, and there are no or few other similar sites in the United Kingdom for comparison, although the record from Cranmer Pond in southeast England comes closest as a highly acidic heathland pool with a diatom flora dominated by Eunotia exigua (Beebee et al., 1990). Unlike the pre-acidification floras of almost all acidified lakes in the United Kingdom so far documented, the basal flora of the pool sediments from Grey Heugh Slack $(15-10 \mathrm{~cm})$ comprises only acid-tolerant taxa. The dominant taxon, Eunotia exigua in particular, is found in waters of very low pH. Frustulia rhomboides var. saxonica and the Pinnularia taxa in the sediments are also acidophilous taxa. The diatom-inferred $\mathrm{pH}$ for these samples using the SWAP training set (Birks et al., 1990) is ca 4.8. This value is similar to the contemporary $\mathrm{pH}$ of UK stream sites, such as Old Lodge, Afon Gwy and Afon Hafren (Kernan et al., 2010), where a similar diatom assemblage occurs at the present day. These modern analogues indicate that Grey Heugh Slack was indeed a very acidic water body in the early 19th century at a time well before the potential impact of acid deposition would have occurred. Such natural acidity for a moorland pool that receives its water input mainly by seepage through surrounding peat is not unexpected given the supply of organic acidity from the peats, the proton generating capacity of Sphagnum (cf. Clymo, 1963) and the apparent lack of any significant input of neutralising base-rich groundwater.

Evidence for the acidification of Grey Heugh Slack comes principally from the marked change in the diatom assemblage at about $10 \mathrm{~cm}$ (c. 1920) when Frustulia rhomboides var. saxonica and the various Pinnularia taxa decline and Eunotia exigua becomes the absolute dominant rising to a relative abundance of c. $90 \%$. There is an increase in the quality of preservation at the same time with the proportion of Frustulia rhomboides var. saxonica valves that are perfectly preserved increasing from less than $10 \%$ to $c$. $60 \%$ (Figure 4 ). This shift in dissolution may have been differential between taxa, but as it represents an improvement in preservation, it cannot account for the decline 
in Frustulia that takes place at the same time. Consequently, we conclude that the shift represents a real change in the assemblage and that the fossil assemblage is a good representation of the living assemblage, a conclusion supported by the very close similarity between the diatom assemblage in the surface sediments of the pool and the contemporary living diatom populations (Battarbee, unpublished).

Although all taxa are acid tolerant, it is clear from other sites in the United Kingdom, including Danby Beck nearby (Shilland et al., 2014), Cranmer Pond (Beebee et al., 1990) in southeast England and elsewhere in Europe (e.g. Kwandrans, 1993; Van Dam et al., 1981), that Eunotia exigua is exceptionally tolerant of low $\mathrm{pH}$. In the Netherlands, from a comparison of diatom samples collected from moorland pools in the 1920s and 1980s, van Dam et al. describe how Eunotia exigua replaced other diatoms including Frustulia rhomboides var. saxonica to become the dominant taxon as the pools became more acidic. Likewise, analysis of a sediment core from Cranmer Pond, an extremely acidic pond in southeast England, showed the same succession (Beebee et al., 1990).

The timing of the increase in Eunotia exigua in Grey Heugh Slack (from the 1920s) lags the increase in the concentration of the acid deposition indicators $\mathrm{Pb}$ and $\mathrm{Hg}$ that occurred during the 19 th century and took place before the change in SCPs and $\delta^{15} \mathrm{~N}$, also acid deposition indicators, in the 1940s. The timing of the change therefore is more likely to reflect a threshold response rather than a direct response to deposition, perhaps indicating that water column acidity begins to increase and Eunotia exigua exerts a competitive advantage over other diatom taxa.

The assemblage change at $c .10 \mathrm{~cm}$ is reflected by the shift in diatom-inferred $\mathrm{pH}$ (Figure 4), although the slight change indicated, from $c$. pH 4.7 to 4.6 , is almost certainly a significant under-estimate of the increase in acidity that is likely to have occurred. The SWAP training set used for the reconstruction (Birks et al., 1990) is one that tends to have a bias to lower values than other pH-inference models (cf. Battarbee et al., 2008) and, of the models available, is therefore the most suitable one to use. However, not even the SWAP training set contains sites with such low $\mathrm{pH}$ values as Grey Heugh Slack. The absence of such highly acidic analogue sites in the training set causes the $\mathrm{pH}$ optimum computed by the model to over-estimate its true value, and the inferred $\mathrm{pH}$ for the upper $10 \mathrm{~cm}$ of the Grey Heugh Slack core is thereby likely to be considerably lower than the inferred value of c. $\mathrm{pH}$ 4.6. Evidence for a more likely value is provided by a comparison with the contemporary data from Danby Beck, Cranmer Pond (Beebee et al., 1990) and Grey Heugh Slack itself. In all cases, the floras are dominated by Eunotia exigua with water $\mathrm{pH}$ of c. 4.0.

Further evidence that the pool has experienced significant acidification during the 20th century is given by the $\mathrm{Zn}$ record in the sediment (Figure 4). Similar to $\mathrm{Hg}$ and $\mathrm{Pb}, \mathrm{Zn}$ increases in concentration through the 19 th century and into the 20th century $(14-10 \mathrm{~cm})$ but then, unlike $\mathrm{Pb}$ and $\mathrm{Hg}$, peaks and declines from about 1920 to the present day. The decline begins at approximately the same time as the main change in the composition of the diatom assemblage. This behaviour is almost certainly not a faithful representation of trends in $\mathrm{Zn}$ deposition, which would not be expected to fall at this time when industrial emissions were rising, but a reflection of $\mathrm{Zn}$ leaching from the sediment into the overlying water as $\mathrm{pH}$ continued to decline (White and Driscoll, 1987).

Except for a very slight increase in the relative abundance of Eunotia curvata (Kützing) Lagerstedt in the top $3 \mathrm{~cm}$, there is very little change in the diatom assemblage in the upper $10 \mathrm{~cm}$ of the core (Figure 4). Although the uppermost $3 \mathrm{~cm}$ covers the period where some recovery from acidification might be expected given the very significant decline in sulphur and nitrogen emissions that occurred locally and nationally as recorded by the deposition collectors at High Muffles, close to the Grey Heugh Slack site, this cannot be regarded as significant, especially as there is little sign of any increase in the abundance of Frustulia rhomboides var. saxonica or other diatoms characteristic of the pre-acidification phase of the pool in the 19th and early 20th century.

This lack of significant recent change is counter to data from the UWMN elsewhere in the United Kingdom where diatom changes have occurred in response to decreasing acid deposition levels as indicated from 20years of diatom monitoring (Battarbee et al., 2014; Kernan et al., 2010). There is also very little evidence of reduction in the concentration of the trace metals $\mathrm{Hg}$ and $\mathrm{Pb}$ in the sediment, despite the marked decline over recent decades in their emissions (http://naei.defra.gov.uk/data/data-selector?view=heavymetals) as noted above.

The lack of significant response so far to the reduction in acid and heavy metal deposition is most probably because of the continuing release of sulphate and trace metals from the surrounding peats that have accumulated over the last 150 years (cf. Daniels et al., 2008). The non-marine sulphate values of $c .150 \mu \mathrm{eqL}^{-1}$ (Table 1) in the pool today (AD 2005) remain exceptionally high. The pre-acidification sulphate values for this site are not known, but non-acidified stream and lake sites in the low acid deposition region of northwest Scotland have values of $10 \mu \mathrm{eqL} \mathrm{L}^{-1}$ or less indicating that sulphate concentrations in the NYM have a long way to fall to reach reference levels. It is probable that the rate of recovery for Grey Heugh Slack and other water bodies in the NYM will be slow, and the legacy of acid deposition in the region will be a long one.

\section{Conclusion}

Analysis of a sediment core from Grey Heugh Slack, a moorland pool in the NYM, shows the pool was formed approximately 220 years ago in a shallow basin probably created by peat cutting. The pool sediments contain a 150 -year record of contamination by air pollutants including trace metals, SCPs and magnetic measurements (indicative of inorganic fly-ash deposition) derived from fossil-fuel combustion, iron and steel manufacture and metal smelting. The sharp increase in SCP accumulation rate and decrease in $\delta^{15} \mathrm{~N}$ values dated to the mid-20th century in the core are in good agreement with the known rapid increase in fossil-fuel combustion in the United Kingdom at that time.

Although the diatom record indicates that the pool has been very acidic since its formation, the increase in Eunotia exigua in the uppermost $9 \mathrm{~cm}$ of the core indicates the pool became even more acidic in the early to mid-20th century, almost certainly as a result of the increased acid deposition that took place.

Small changes in the diatom assemblage in the top $3 \mathrm{~cm}$ of the core provide evidence that some recovery may be taking place, but the pool today remains exceptionally acidic, despite the major reductions in sulphur and nitrogen deposition that have occurred over the last 30 years. We believe that the extreme acidity of Grey Heugh Slack and other similar surface waters in the NYM reflects the continuing influence of pollutant sulphur stored in catchment peats, a legacy of 150 years of acid deposition.

\section{Acknowledgements}

We thank Chris Evans for suggesting Grey Heugh Slack as a potential study site and for providing hydrochemical data, Tom Chadwick for helpful discussions on the North York Moors and provision of data for Danby Beck, Hong Yang for help with fieldwork and for data on contemporary diatom populations and Miles Irving for providing artwork. FO thanks Mike O'Connor for carrying out the magnetic measurements. We dedicate this paper to John Birks whose pioneering work on diatom-pH transfer functions underpinned our 'acid rain' projects of the 1980s, and we 
offer it as a multi-authored, multi-proxy study designed to embody the spirit of SWAP that he did so much to make successful.

\section{Funding}

This research received no specific grant from any funding agency in the public, commercial or not-for-profit sectors

\section{References}

Almer B, Dickson W, Ekström C et al. (1974) Effects of acidification on Swedish lakes. Ambio 3: 30-36.

Appleby PG and Oldfield F (1978) The calculation of $210 \mathrm{~Pb}$ dates assuming a constant rate of supply of unsupported $210 \mathrm{~Pb}$ to the sediment. Catena 5: 1-8.

Appleby PG, Richardson N and Nolan PJ (1992) Self-absorption corrections for well-type germanium detectors. Nuclear Instruments and Methods in Physics Research Section B: Beam Interactions with Materials and Atoms 71: 228-233.

Appleby PG, Nolan PJ, Gifford DW et al. (1986) Pb-210 dating by low background gamma counting. Hydrobiologia 143: 21-27.

Atherden MA (1979) Late Quaternary vegetational history of the North York Moors VII. Pollen diagrams from the eastern-central area. Journal of Biogeography 6: 63-83.

Battarbee RW, Anderson NJ, Appleby PG et al. (1988) Lake Acidification in the United Kingdom 1800-1986: Evidence from Analysis of Lake Sediments. London: ENSIS Ltd.

Battarbee RW, Carvalho L, Jones VJ et al. (2001) Diatoms. In: Smol JP, Last W and Birks HJB (eds) Tracking Environmental Change Using Lake Sediments: Terrestrial, Algal, and Siliceous Indicators, vol. 3. Dordrecht: Kluwer Academic Publishers, pp. 155-202.

Battarbee RW, Flower RJ, Stevenson AC et al. (1985) Lake acidification in Galloway - A palaeoecological test of computing hypotheses. Nature 314: 350-352.

Battarbee RW, Monteith DT, Juggins S et al. (2008) Assessing the accuracy of diatom-based transfer functions in defining reference $\mathrm{pH}$ conditions for acidified lakes in the United Kingdom. The Holocene 18: 57-67.

Battarbee RW, Shilland EM, Kernan M et al. (2014) Recovery of acidified surface waters from acidification in the United Kingdom after twenty years of chemical and biological monitoring (1988-2008). Ecological Indicators 37: 267-273.

Beebee TJC, Flower RJ, Stevenson AC et al. (1990) Decline of the natterjack toad Bufo calamita in Britain: Palaeoecological, documentary and experimental evidence for breeding site acidification. Biological Conservation 53: 1-20.

Bennion H, Hilton J, Hughes M et al. (2005) The use of a GISbased inventory to provide a national assessment of standing waters at risk from eutrophication in Great Britain. Science of the Total Environment 344: 259-273.

Birks HJB, Line JM, Juggins S et al. (1990) Diatoms and $\mathrm{pH}$ reconstruction. Philosophical Transactions of the Royal Society of London Series B: Biological Sciences 327: 263-278.

Blaauw M and Christen JA (2011) Flexible paleoclimate agedepth models using an autoregressive gamma process. Bayesian Analysis 6: 457-474.

Chadwick T (2001) Monitoring Acid Rain on the North York Moors: Summary Report of a Ten Year Programme of Monitoring from 1990 to 2000. Whitby: Environet Environmental Monitoring.

Clymo RS (1963) Ion exchange in Sphagnum and its relation to bog ecology. Annals of Botany 27: 309-324.

Cookson G (2009) Danby Manor and Court. Whitby: Whitby Literary and Philosophical Society.

Critical Loads Advisory Group (CLAG) (1995) Critical Loads of Acid Deposition for United Kingdom Freshwaters. Sub group
Report on Freshwaters, September. Penicuik: Institute of Terrestrial Ecology (Edinburgh Research Station).

Curtis CJ and Simpson GL (2011) Defra Freshwater Umbrella Programme - The Effect of Nitrogen Deposition on Freshwaters in the UK. ECRC Research Report No 115. London: Environmental Change Research Centre, University College London.

Daniels SM, Evans MG, Agnew CT et al. (2008) Sulphur leaching from headwater catchments in an eroded peatland, South Pennines, U.K. Science of the Total Environment 407: 481-496.

De Vries H and Barendsen G (1952) A new technique for the measurement of age by radiocarbon. Physica 18: 652 .

Evans CD, Chadwick T, Norris D et al. (2014) Persistent surface water acidification in an organic soil-dominated upland region subject to high atmospheric deposition: The North York Moors, UK. Ecological Indicators 37: 304-316.

Flower RJ and Battarbee RW (1983) Diatom evidence for recent acidification of two Scottish lochs. Nature 305: 130-133.

Gälman V, Rydberg J and Bigler C (2009) Decadal diagenetic effects on delta C-13 and delta N-15 studied in varved lake sediment. Limnology and Oceanography 54: 917-924.

Harriman R and Morrison BRS (1982) Ecology of streams draining forested and non-forested catchments in an area of central Scotland subject to acid deposition. Hydrobiologia 88 : 252-263.

Hastings MG, Jarvis JC and Steig EJ (2009) Anthropogenic impacts on nitrogen isotopes of ice-core nitrate. Science 324: 1288.

Henriksen A, Kamari J, Posch M et al. (1992) Critical loads of acidity - Nordic surface waters. Ambio 21: 356-363.

Holtgrieve GW, Schindler DE, Hobbs WO et al. (2011) A coherent signature of anthropogenic nitrogen deposition to remote watersheds of the Northern Hemisphere. Science 334: 15451548.

Innes JB and Simmons IG (2000) Mid-Holocene charcoal stratigraphy, fire history and palaeoecology at North Gill, North York Moors, UK. Palaeogeography, Palaeoclimatology, Palaeoecology 164: 151-165.

Innes JB, Blackford J and Simmons I (2010) Woodland disturbance and possible land-use regimes during the Late Mesolithic in the English uplands: Pollen, charcoal and non-pollen palynomorph evidence from Bluewath Beck, North York Moors, UK. Vegetation History and Archaeobotany 19: 439452.

Jensen KW and Snekvik E (1972) Low pH levels wipe out salmon and trout populations in southernmost Norway. Ambio 1: 223-225.

Kernan M, Battarbee RW, Curtis CJ et al. (2010) UK Acid Waters Monitoring Network 20 Year Interpretative Report. London: ENSIS Ltd, Environmental Change Research Centre, University College London.

Kopáček J, Borovec J, Hejzlar J et al. (2005) Aluminum control of phosphorus sorption by lake sediments. Environmental Science \& Technology 39: 8784-8789.

Kreiser AM, Patrick ST and Battarbee RW (1993) Critical acidity loads for UK freshwaters - Introduction, sampling strategy and use of maps. In: Hornung $M$ and Skeffington RA (eds) Critical Loads: Concept and Applications. London: HMSO, pp. 94-98.

Kwandrans J (1993) Diatom communities of acidic mountain streams in Poland. Hydrobiologia 269: 335-342.

Lomonte C, Gregory D, Baker AJM et al. (2008) Comparative study of hotplate wet digestion methods for the determination of mercury in biosolids. Chemosphere 72: 1420-1424.

Mason BJ (1990) The Surface Waters Acidification Programme. Cambridge: Cambridge University Press. 
Monteith DT, Evans CD, Henrys PA et al. (2014) Trends in the hydrochemistry of acid-sensitive surface waters in the UK 1988-2008. Ecological Indicators 37: 287-303.

Moore PD (1975) Origin of blanket mires. Nature 256: 267-269.

Moore PD, Webb JA and Collinson ME (1991) Pollen Analysis. Oxford: Blackwell.

National Atmospheric Emissions Inventory (2014) http://naei. defra.gov.uk/

Nilsson J and Grennfelt P (1988) Critical Loads for Sulphur and Nitrogen. Copenhagen: Nordic Council for Ministers.

Oldfield F (2013) Mud and magnetism: Records of late Pleistocene and Holocene environmental change recorded by magnetic measurements. Journal of Paleolimnology 49: 465-480.

Oldfield F, Barnosky C, Leopold EB et al. (1983) Mineral magnetic studies of lake sediments - A brief review. Hydrobiologia 103: 37-44.

Oldfield F, Gedye S, Hunt A et al. (IN PRESS) The magnetic record of inorganic fly ash deposition in lake sediments and ombrotrophic peats. The Holocene.

Patrick ST, Waters D, Juggins S et al. (1991) The United Kingdom Acid Waters Monitoring Network: Site Descriptions and Methodology Report. London: ENSIS Ltd.

Reimer PJ, Bard E, Bayliss A et al. (2013) IntCal13 and marine13 radiocarbon age calibration curves $0-50,000$ years cal. BP. Radiocarbon 55: 1869-1887.

Rippey B (1990) Sediment chemistry and atmospheric contamination. Philosophical Transactions of the Royal Society of London Series B: Biological Sciences 327: 311-317.

Rose NL (1994) Characterisation of carbonaceous particles from lake sediments. Hydrobiologia 274: 127-132.

Rose NL (2001) Fly-ash particles. In: Last WM and Smol JP (eds) Tracking Environmental Change Using Lake Sediments, vol. 2: Physical and Geochemical Methods. Dordrecht: Kluwer Academic Publishers, pp. 319-350.

Rose NL (2008) Quality control in the analysis of lake sediments for spheroidal carbonaceous particles. Limnology and Oceanography-Methods 6: 172-179.

Rose NL and Appleby PG (2005) Regional applications of lake sediment dating by spheroidal carbonaceous particle analysis I: United Kingdom. Journal of Paleolimnology 34: 349-361.

Rose NL, Yang HD, Turner SD et al. (2012) An assessment of the mechanisms for the transfer of lead and mercury from atmospherically contaminated organic soils to lake sediments with particular reference to Scotland, UK. Geochimica et Cosmochimica Acta 82: 113-135.
Ruppel M, Valiranta M, Virtanen T et al. (2013) Postglacial spatiotemporal peatland initiation and lateral expansion dynamics in North America and northern Europe. The Holocene 23: 1596-1606.

Ryves DB, Battarbee RW and Fritz SC (2009) The dilemma of disappearing diatoms: Incorporating diatom dissolution data into palaeoenvironmental modelling and reconstruction. Quaternary Science Reviews 28: 120-136.

Shilland EM, Monteith DT, Millidine K et al. (2014) The United Kingdom Upland Waters Monitoring Network Data Report for 2012-2013 (year 25). Report to the Department for Environment, Food and Rural Affairs (Contract EPG 1/3/160) London: Environmental Change Research Centre, University College London, pp. 1-260.

Simmons IG and Cundill PR (1974) Late Quaternary vegetational history of the North York Moors. I: Pollen analyses of blanket peats. Journal of Biogeography 1: 159-169.

Slota PJ, Jull AJT, Linick TW et al. (1987) Preparation of small samples for C-14 accelerator targets by catalytic reduction of Co. Radiocarbon 29: 303-306.

Stevenson AC, Juggins S, Birks HJB et al. (1991) The Surface Waters Acidification Project Palaeolimnology Programme: Modern Diatom/Lake-Water Chemistry Data-Set. London: ENSIS Ltd.

Stuiver M and Polach HA (1977) Reporting of C-14 data - Discussion. Radiocarbon 19: 355-363.

Turner J, Innes JB and Simmons IG (1993) Spatial diversity in the mid-Flandrian vegetation history of North Gill, North Yorkshire. New Phytologist 123: 599-647.

Van Dam H, Suurmond G and Ter Braak CJF (1981) Impact of acidification on diatoms and chemistry of Dutch moorland pools. Hydrobiologia 83: 425-460.

Weng LP, Temminghoff EJM, Lofts S et al. (2002) Complexation with dissolved organic matter and solubility control of heavy metals in a sandy soil. Environmental Science \& Technology 36: 4804-4810.

White JR and Driscoll CT (1987) Zinc cycling in an acidic Adirondack lake. Environmental Science \& Technology 21: 211-216.

Wright RF, Harriman R, Henriksen A et al. (1980) Acid lakes and streams in the Galloway area, south-western Scotland. In: Drabløs D and Tollan A (eds) Ecological Impact of Acid Precipitation: Proceedings of an International Conference, Sandefjord, 11-14 March. Oslo: SNSF Project, pp. 248-249.

Yang HD, Rose NL, Battarbee RW et al. (2002) Mercury and lead budgets for Lochnagar, a Scottish mountain lake and its catchment. Environmental Science \& Technology 36: 1383-1388. 